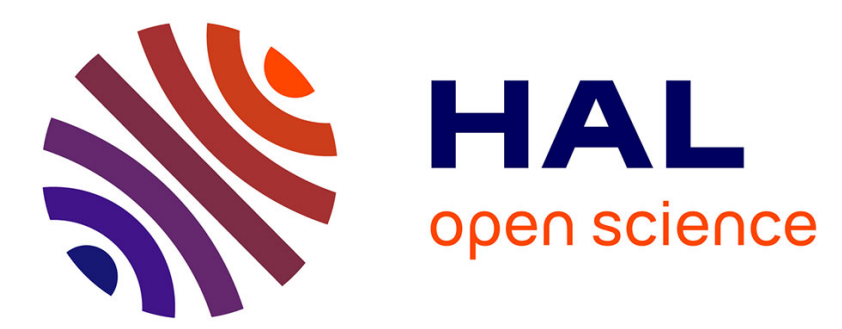

\title{
The OH-F substitution in synthetic pargasite at 1.5 kbar, $850{ }^{\circ} \mathrm{C}$.
}

Jean-Louis Robert, Giancarlo Della Ventura, Mark D. Welch, Franck C. Hawthorne

\section{> To cite this version:}

Jean-Louis Robert, Giancarlo Della Ventura, Mark D. Welch, Franck C. Hawthorne. The OH-F substitution in synthetic pargasite at $1.5 \mathrm{kbar}, 850{ }^{\circ} \mathrm{C}$.. American Mineralogist, 2000, 85, pp.926-931. hal-00077556

\section{HAL Id: hal-00077556 https://hal-insu.archives-ouvertes.fr/hal-00077556}

Submitted on 31 May 2006

HAL is a multi-disciplinary open access archive for the deposit and dissemination of scientific research documents, whether they are published or not. The documents may come from teaching and research institutions in France or abroad, or from public or private research centers.
L'archive ouverte pluridisciplinaire HAL, est destinée au dépôt et à la diffusion de documents scientifiques de niveau recherche, publiés ou non, émanant des établissements d'enseignement et de recherche français ou étrangers, des laboratoires publics ou privés. 


\title{
The OH-F substitution in synthetic pargasite at $1.5 \mathrm{kbar}, 850{ }^{\circ} \mathrm{C}$
}

\section{Jean-Louis Robert, ${ }^{1}$ Giancarlo Della Ventura, ${ }^{2, *}$ Mark D. Welch, ${ }^{3}$ AND FRANK C. HAWTHORNE ${ }^{4}$}

\author{
${ }^{1}$ CRSCM-CNRS, 1A, Rue de la Férollerie, F-45071, Orléans Cedex 2, France \\ ${ }^{2}$ Dipartimento di Scienze della Terra, Università della Calabria, Arcavacata di Rende, I-87030 (CS), Italy \\ ${ }^{3}$ Department of Mineralogy, The Natural History Museum, Cromwell Road, London SW7 5BD, U.K. \\ ${ }^{4}$ Department of Geological Sciences, University of Manitoba, Winnipeg, Manitoba R3T 2N2, Canada
}

\begin{abstract}
Amphiboles were synthesized at $1.5 \mathrm{kbar} P_{\mathrm{H}_{2} \mathrm{O}}$ and $850^{\circ} \mathrm{C}$ along the join pargasite-fluoropargasite. Structural variations in the amphibole as a function of $\mathrm{F}$ have been characterized by a combination of SEM-EDS, X-ray powder diffraction, and infrared spectroscopy. SEM-EDS analyses show that, for increasing $\mathrm{F}$ in the system, there is a decrease in $\mathrm{Al}_{\mathrm{tot}}$ in the amphibole and a significant decrease of $\mathrm{F}$ incorporation in the structure. In agreement with the EDS data, the variation in cell parameters and IR spectra show that incorporation of $\mathrm{F}$ in pargasite is restricted to about 1.0 atoms per formula unit (apfu). The $\mathrm{OH}$-stretching spectra show fine structure caused by $\mathrm{F}$ replacing $\mathrm{OH}$ at the $\mathrm{O} 3$ anion site, and are consistent with two-mode behavior typical of A-site-filled amphiboles. The agreement between calculated and observed relative band intensities suggests complete short-range disorder of $\mathrm{OH}$ and $\mathrm{F}$ at the $\mathrm{O} 3$ anion site.
\end{abstract}

\section{INTRODUCTION}

Amphiboles containing significant amounts of $\mathrm{F}$ are common in syenites, granites, and siliceous marbles (Petersen et al. 1982). It is well established that F increases markedly the thermal and baric stabilities of amphiboles (Cameron and Gibbs 1973; Foley 1991; Valley et al. 1982). Fluorine-hydroxyl exchange between minerals is used as a geothermometer (e.g., Westrich 1981), and fluoro-amphiboles have been used as experimental analogues of their hydroxyl counterparts because of their relative ease of synthesis, characterization and stability in calorimetric experiments (Holloway and Ford 1975; Graham and Navrotsky 1986). In some cases, this procedure has been applied successfully (e.g., Welch and Graham 1992). However, much of the utility of the approach of using $\mathrm{F}$ analogues in amphibole studies depends upon the characterization of cation and $\mathrm{F}-\mathrm{OH}$ ordering. Long-range ordering patterns of cations in pargasite are now quite well understood (Raudsepp et al. 1987; Welch et al. 1994; Oberti et al. 1995a, 1998), even if we still know very little about short-range ordering (Della Ventura et al. 1999a). Welch and Knight (1999) studied synthetic end-member pargasite by neutron powder-diffraction and found ${ }^{[6]} \mathrm{Al}$ disordered over M2 and M3, but not M1, in accord with single-crystal X-ray data on natural pargasites (Oberti et al. 1995a). On the other hand, the ordering of octahedral cations in pargasite is significantly affected by the presence of $\mathrm{F}$ such that trivalent cations are strongly ordered at the M2 site in fluoro-pargasite (Raudsepp et al. 1987; Oberti et al. 1995b, 1998).

Both pargasite (Boyd 1959; Gilbert 1969; Holloway 1973; Semet 1973; Hinrichsen and Schürman 1977; Braue and Seck 1977; Oba 1980; Westrich and Holloway 1981; Raudsepp et

*E-mail: dellaven@unical.it al. 1987; Welch et al. 1994, 1998; Della Ventura et al. 1999a, 1999b) and fluoro-pargasite (Westrich and Navrotsky 1981; Raudsepp et al. 1987; Oberti et al. 1995b) have been synthesized and characterized. However, there is no data for synthetic pargasite with intermediate OH-F compositions. This lack of information prompted the present work, focused on the synthesis and characterization of amphiboles along the join pargasite-fluoro-pargasite.

\section{EXPERIMENTAL METHODS}

Starting materials were prepared as silicate gels according to the method of Hamilton and Henderson (1968). For F-bearing pargasite, $\mathrm{F}$ was added as dried $\mathrm{MgF}_{2}$ to a gel of appropriate composition. A constant solid/water ratio of $10 \%$ by weight was used for all experiments. Synthesis was done at $850{ }^{\circ} \mathrm{C}$, $1.5 \mathrm{kbar}$ in Tuttle-type, externally heated pressure vessels for the duration of one week. FTIR spectra in the principal $\mathrm{OH}-$ stretching region (4000-3000 $\left.\mathrm{cm}^{-1}\right)$ were collected on a Nicolet Magna 760 spectrophotometer equipped with a nitrogen-cooled InSb detector and $\mathrm{a} \mathrm{CaF}_{2}$ beamsplitter; the nominal resolution is $2 \mathrm{~cm}^{-1}$ and final spectra are the average of 32 scans. Samples were prepared as $\mathrm{KBr}$ pellets. Details of the sample preparation may be found in Robert et al. (1989). To minimize interfering moisture in the pellets, the mineral $+\mathrm{KBr}$ powders were dried at $150{ }^{\circ} \mathrm{C}$ for 24 hours and then pressed. All disks were kept in an oven $\left(150^{\circ} \mathrm{C}\right)$ overnight and then analyzed at room temperature in controlled atmosphere. Despite careful sample preparation, some moisture was still present in all samples. $\mathrm{X}$-ray powder-diffraction patterns were recorded with Fe-filtered CoK $\alpha$ X-radiation. Cell parameters were measured by whole powder-pattern refinement (Rietveld method) using the DBW3.2 software package (Wiles and Young 1981). Due to the very small grain-size, chemical analyses were done by SEMEDAX on powders mounted on carbon tape on a brass sub- 
strate $(\mathrm{Cu}, \mathrm{Zn})$. For each sample, a suitable number of amphibole crystals with flat surfaces were analyzed. EDS analyses were acquired on a Philips XL30 high-resolution electron-microscope at LIME (Laboratorio Interdipartimentale di Microscopia Elettronica, University of Roma Tre) equipped with a Super-UTW EDAX detector with a focused beam for 150 s count-time. Data were corrected for ZAF effects and the relative concentrations were obtained by standardless analysis; the values obtained are believed to be reliable within $10 \%$ relative.

\section{RESULTS}

\section{Run products}

Run products were examined by optical microscopy, SEM, and X-ray powder-diffraction. For all compositions, the run product consists of amphibole plus a minor amount of mica. The amount of mica increases slightly with increasing F content in the system. Considering the bulk composition of the starting materials and the presence of diffraction peaks corresponding to (001) repeats of 15,12 , and $10 \AA$, we conclude that the composition of this mica is close to that of Na-phlogopite and its two hydrates (Carman 1974). The pargasite and fluoro-pargasite crystals (Fig. 1) are acicular, averaging 2-3 $\mu \mathrm{m} \times 10 \mu \mathrm{m}$, with a few larger crystals up to $4-5 \mu \mathrm{m} \times 15 \mu \mathrm{m}$.

\section{Chemical composition}

The data of Table 1 show that, for increasing F content in the system, there is a decrease in total $\mathrm{Al}$ in the amphibole, the composition of which departs from pargasite stoichiometry toward edenite, according to the Tschermak-type substitution ${ }^{[6]} \mathrm{Al}+{ }^{[4]} \mathrm{Al} \leftrightarrow{ }^{[6]} \mathrm{Mg}+{ }^{[4]} \mathrm{Si}$. The EDS data show constant $\mathrm{Na}$ and $\mathrm{Ca}$ contents across the join. The crystal-chemical formula of the amphibole solid-solution can be thus expressed as $\mathrm{Na}$ $\mathrm{Ca}_{2}\left(\mathrm{Mg}_{4+x} \mathrm{Al}_{1-x}\right)\left(\mathrm{Si}_{6+x} \mathrm{Al}_{2-x}\right) \mathrm{O}_{22}(\mathrm{OH}, \mathrm{F})_{2}$, where $x$ is the amount of edenite component in the amphibole. It is apparent from Table 1 that for nominal F contents greater than $1.2 \mathrm{apfu}$ in the system there is a sudden and significant departure toward edenite and that the $\mathrm{F}$ content in the amphibole is virtually constant.

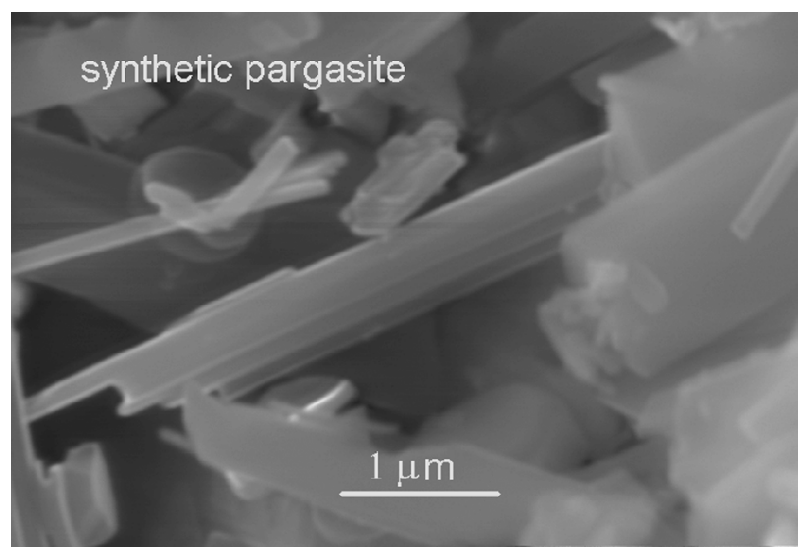

FIGURE 1. SEM image of synthetic pargasite.

\section{Unit-cell parameters}

Table 2 gives the unit-cell parameters of the synthetic amphiboles. The most notable feature (Fig. 2) is the strong decrease of the $a$ edge with $X_{\mathrm{F}}=\mathrm{F} /[\mathrm{OH}+\mathrm{F}]$, up to $X_{\mathrm{F}} \sim 0.5$. The $b$ edge decreases slightly in the same compositional range, and then increases slightly for $X_{\mathrm{F}}>0.5$. The $c$ edge increases slightly up to $X_{\mathrm{F}} \sim 0.5$, and then remains constant for higher $\mathrm{F}$ contents. The $\beta$ angle decreases in the range $0.0<X_{\mathrm{F}}<0.5$ and is almost constant for $X_{\mathrm{F}}>0.5$. This strongly anisotropic variation of the cell parameters as a function of $F$ parallels the behavior observed for (OH,F)-richterite (Robert et al. 1989). In richterite, there is virtually complete exchange between $\mathrm{OH}$ and $\mathrm{F}$ at the O3 site (Robert et al. 1989, 1999) and the linear contraction of the cell volume, as a function of $\mathrm{F}$ (Fig. 3) occurs because $\mathrm{F}^{-1}$ is smaller than $\mathrm{O}^{-1}$ (1.30 vs. $1.34 \AA$, Shannon 1976). In F-substituted pargasite, the cell volume decreases only up to $X_{\mathrm{F}}=$ 0.5 . Figures 2 and 3 suggest that, in pargasite, at least for the hydrothermal conditions used here, the incorporation of $\mathrm{F}$ is restricted to about $1.0 \mathrm{apfu}$, in accord with the EDS analyses (Table 1). For $X_{\mathrm{F}}>0.5$, the unit-cell volume and the $b$ edge of the synthesized amphibole increase markedly. This cannot be related to the $\mathrm{OH} \rightarrow \mathrm{F}$ substitution in the amphibole, and is in accord with the increasing amount of edenite component in the amphibole detected by EDS.

\section{Infrared spectroscopy}

The spectrum of end-member pargasite (Fig. 4) shows a doublet consisting of two rather broad bands (A and B) of almost equal intensity, centered at 3710 and $3678 \mathrm{~cm}^{-1}$, which are conventionally assigned to the $\mathrm{MgMgMg}-\mathrm{OH}-\mathrm{Na}$ and MgMgAl-OH-Na configurations, respectively (Semet 1973; Raudsepp et al. 1987; Welch et al. 1994; Della Ventura et al. 1999a, 1999b). In the spectra of pargasite of intermediate $\mathrm{OH}-$ F contents, each of these two bands is replaced by a new band ( $\mathrm{A}^{\prime}$ and $\mathrm{B}^{\prime}$ ) at lower wavenumber. The position of these new bands is constant for any anion composition, and their intensity is related to the amount of $\mathrm{F}$ in the amphibole; the A- $\mathrm{A}^{\prime}$ and $\mathrm{B}-\mathrm{B}^{\prime}$ band-separations are 15 and $20 \mathrm{~cm}^{-1}$, respectively.

TABLE 1. Microchemical data (average on ten point analyses) for amphiboles along the join pargasite-fluoropargasite

\begin{tabular}{lccccc}
\hline \hline Sample & $\mathrm{Al} /(\mathrm{Al}+\mathrm{Si})$ & $\begin{array}{c}X_{\text {EDE }} \\
\mathrm{mol} \%\end{array}$ & $\begin{array}{c}F_{\text {nom }} \\
\text { apfu }\end{array}$ & $\begin{array}{c}F_{\text {nom }} \\
(\mathrm{wt} \%)\end{array}$ & $\begin{array}{c}F_{\text {obs }} \\
(\mathrm{wt} \%)\end{array}$ \\
\hline F25A & 0.33 & 2.7 & 0.00 & 0.00 & 0.00 \\
F21 & 0.32 & 8.4 & 0.40 & 0.91 & $1.0(2)$ \\
$\mathrm{F} 22$ & 0.32 & 8.8 & 0.80 & 1.82 & $2.3(4)$ \\
$\mathrm{F} 23$ & 0.32 & 7.2 & 1.20 & 2.72 & $2.9(2)$ \\
F24 & 0.29 & 20.6 & 1.60 & 3.62 & $3.4(7)$ \\
F25 & 0.29 & 24.0 & 2.00 & 4.52 & $3.7(3)$ \\
\hline \multicolumn{7}{l}{ Note: $X_{\text {EDE }}$ is the edenite component. }
\end{tabular}

TABLE 2. Unit-cell parameters of synthetic amphiboles along the join pargasite-fluoropargasite

\begin{tabular}{lcccccc} 
Sample & $X_{\mathrm{F}}(\mathrm{nom})$ & $a(\AA)$ & $b(\AA)$ & $c(\AA)$ & $\beta\left(^{\circ}\right)$ & $V\left(\AA^{3}\right)$ \\
\hline F25A & 0.00 & $9.900(3)$ & $17.928(5)$ & $5.278(2)$ & $105.55(2)$ & 902.49 \\
F21 & 0.20 & $9.867(1)$ & $17.921(2)$ & $5.2850(2)$ & $105.394(7)$ & 901.06 \\
F22 & 0.40 & $9.846(1)$ & $17.914(2)$ & $5.2869(6)$ & $105.323(6)$ & 899.40 \\
F23 & 0.60 & $9.832(1)$ & $17.913(2)$ & $5.2906(5)$ & $105.260(5)$ & 898.99 \\
F24 & 0.80 & $9.830(1)$ & $17.919(2)$ & $5.2909(7)$ & $105.212(7)$ & 899.38 \\
F25 & 1.00 & $9.833(2)$ & $17.930(4)$ & $5.289(5)$ & $105.18(5)$ & 900.02 \\
\hline
\end{tabular}




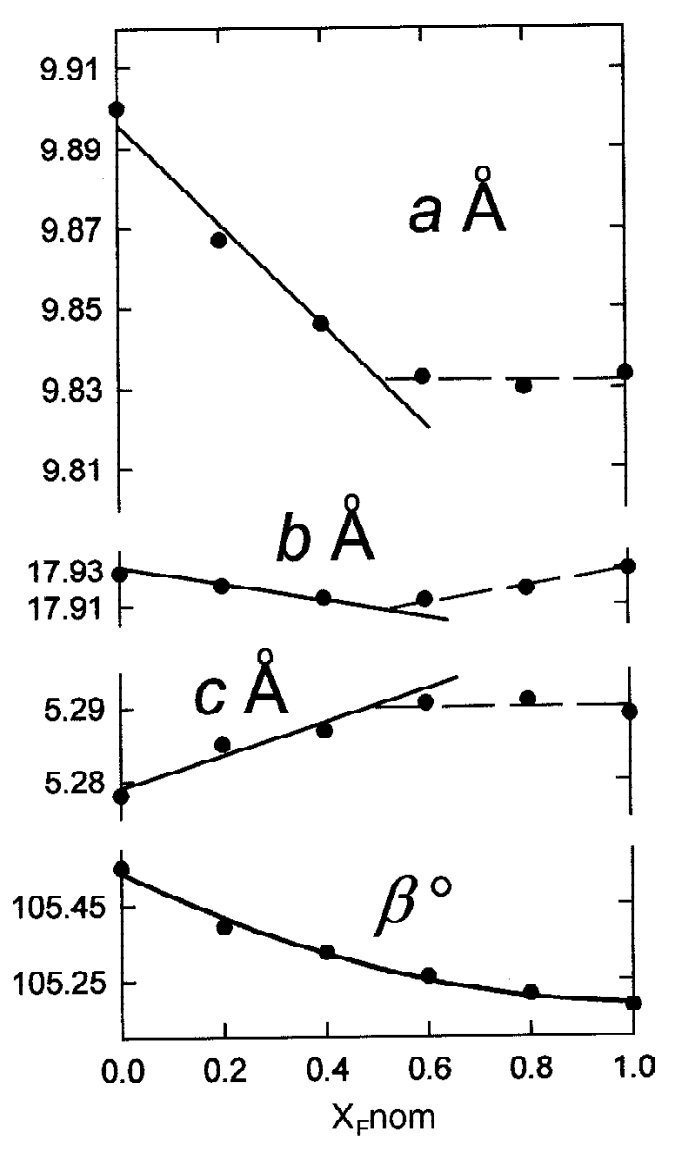

FIGURE 2. Variation in unit-cell parameters of amphiboles along the join pargasite-fluoropargasite as a function of nominal $X_{\mathrm{F}}=\mathrm{F} /[\mathrm{OH}+\mathrm{F}]$.

The behavior observed here for pargasite is similar to that observed for richterite and can be classified as two-mode behavior (Della Ventura et al. 1993).

The spectra of intermediate compositions were decomposed into four symmetrical Gaussian bands following the method of Della Ventura et al. $(1996,1997)$. Some selected results are shown in Figure 5, and Table 3 gives the refined position, width, and intensity for each component band. The spectrum of endmember pargasite was resolved into two main bands, A and B, plus an additional low-intensity band at $3652 \mathrm{~cm}^{-1}$ (A*, Fig. 5). Recent work of Della Ventura et al. (1999a) shows that the spectrum of end-member pargasite is much more complicated than the present model indicates, due to short-range ordering of cations at both NN (nearest-neighbor) and NNN (next-nearest-neighbor) sites. However, in the present case, most of the discussion focuses on substitutions at the anion site, and a simplified four-band model is adequate. The minor $\mathrm{A}^{*}$ band is assigned to the $-\mathrm{MgMgMg}$ configuration (Raudsepp et al. 1987; Della Ventura et al. 1999a) and suggests that nominal end-member pargasite departs slightly from its ideal composition toward magnesiohornblende; the relative intensity of the $A^{*}$ band is $11 \%$ of the total absorbance (Table 3 ). The A* band partly overlaps with the F-related B' band (Fig. 5), so it was removed from the refinement and the intensity of the B' band has been corrected for all samples by systematic subtraction of $5 \%$ of the intensity. We have no way to know if the amount of vacant A-

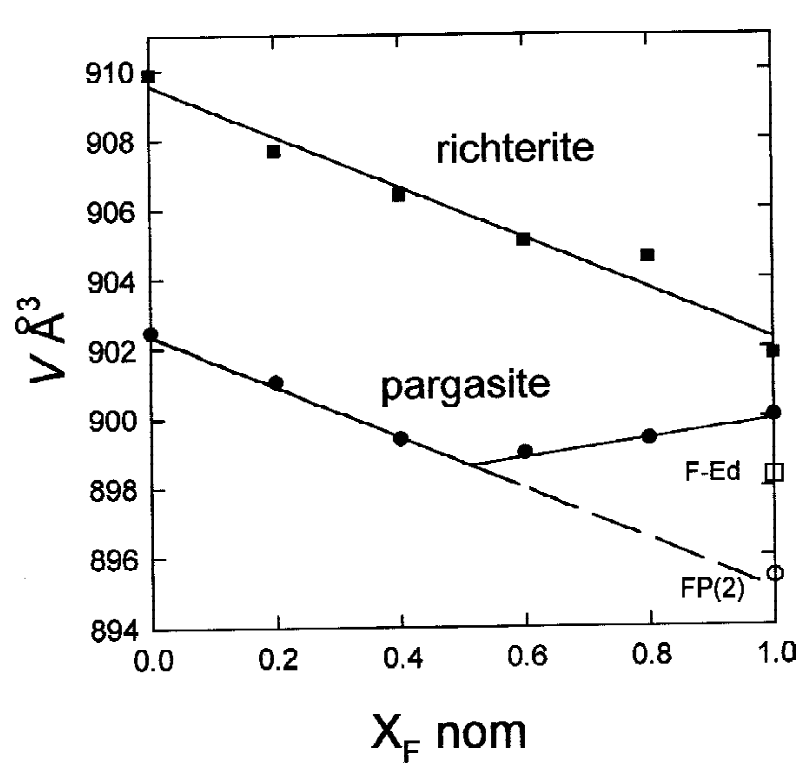

FIGURE 3. Variation in unit-cell volume of synthetic amphiboles as a function of $X_{\mathrm{F}}$ along the join pargasite-fluoropargasite (filled circles) and along the join richterite-fluororichterite (filled squares = Robert et al. 1989) and of synthetic end-members fluoropargasite (open circle = sample FP(2), Oberti et al. 1995b) and fluoroedenite (open square $=$ Boshmann et al. 1994).

TABLE 3. Refined positions $\left(\mathrm{cm}^{-1}\right)$, widths $\left(\mathrm{cm}^{-1}\right)$ and relative intensities (area) of amphiboles along the pargasitefluoropargasite join

\begin{tabular}{lllllll}
\hline \hline Sample & & $\mathrm{A}$ & $\mathrm{A}^{\prime}$ & $\mathrm{B}$ & $\mathrm{B}^{\prime}$ & $\mathrm{A}^{*}$ \\
\hline \multirow{4}{*}{ F25A } & Position & 3711 & - & 3679 & - & 3652 \\
& Width & 21.0 & - & 26.1 & - & 26.4 \\
& Area & 0.40 & - & 0.49 & - & 0.11 \\
& & & & & & \\
F21 & Position & 3711 & 3693 & 3678 & 3656 & - \\
& Width & 20.6 & 20.7 & 26.2 & 26.2 & - \\
& Area & 0.37 & 0.11 & 0.38 & 0.14 & - \\
& & & & & & \\
F22 & Position & 3711 & 3693 & 3678 & 3660 & - \\
& Width & 20.6 & 20.7 & 26.2 & 26.2 & - \\
& Area & 0.30 & 0.23 & 0.25 & 0.22 & - \\
& & & & & & \\
F23 & Position & 3710 & 3692 & 3678 & 3661 & - \\
& Width & 20.6 & 20.7 & 26.2 & 26.2 & - \\
& Area & 0.21 & 0.38 & 0.11 & 0.29 & - \\
& & & & & & \\
F24 & Position & 3709 & 3693 & 3678 & 3659 & - \\
& Width & 20.4 & 20.4 & 26.2 & 26.0 & - \\
& Area & 0.16 & 0.41 & 0.14 & 0.29 & - \\
& & & & & & \\
F25 & Position & 3708 & 3693 & 3678 & 3659 & - \\
& Width & 20.6 & 20.4 & 26.2 & 26.1 & - \\
& Area & 0.16 & 0.46 & 0.10 & 0.28 & - \\
\hline
\end{tabular}

sites is constant across the series. However, the error introduced in the calculation of the relative band intensities is averaged over all bands, and can be considered to be less than 5\%, i.e., well within the limit of the method.

\section{DISCUSSION}

\section{The OH-F distribution in pargasite}

The variation in relative band intensities in the spectra of intermediate (OH-F) amphiboles may be explained by consid- 


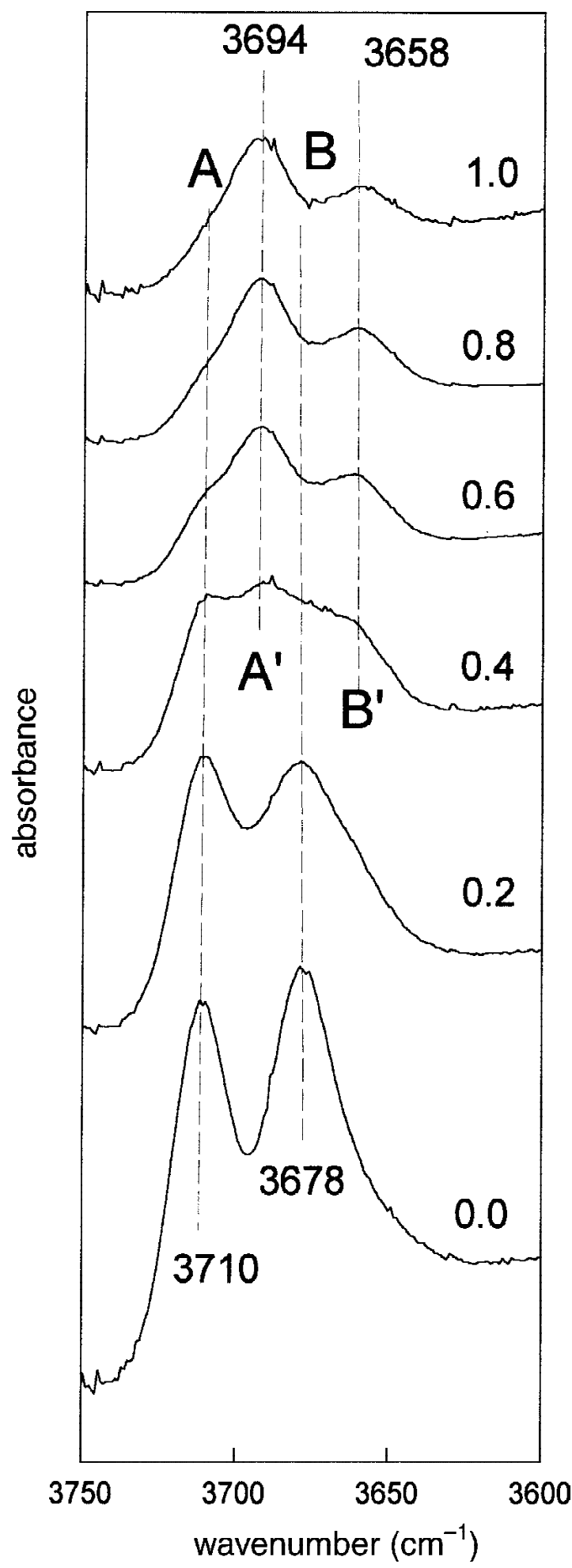

FIGURE 4. FTIR spectra in the OH-stretching region for the amphiboles with different $X_{\mathrm{F}}$. See text for band nomenclature.

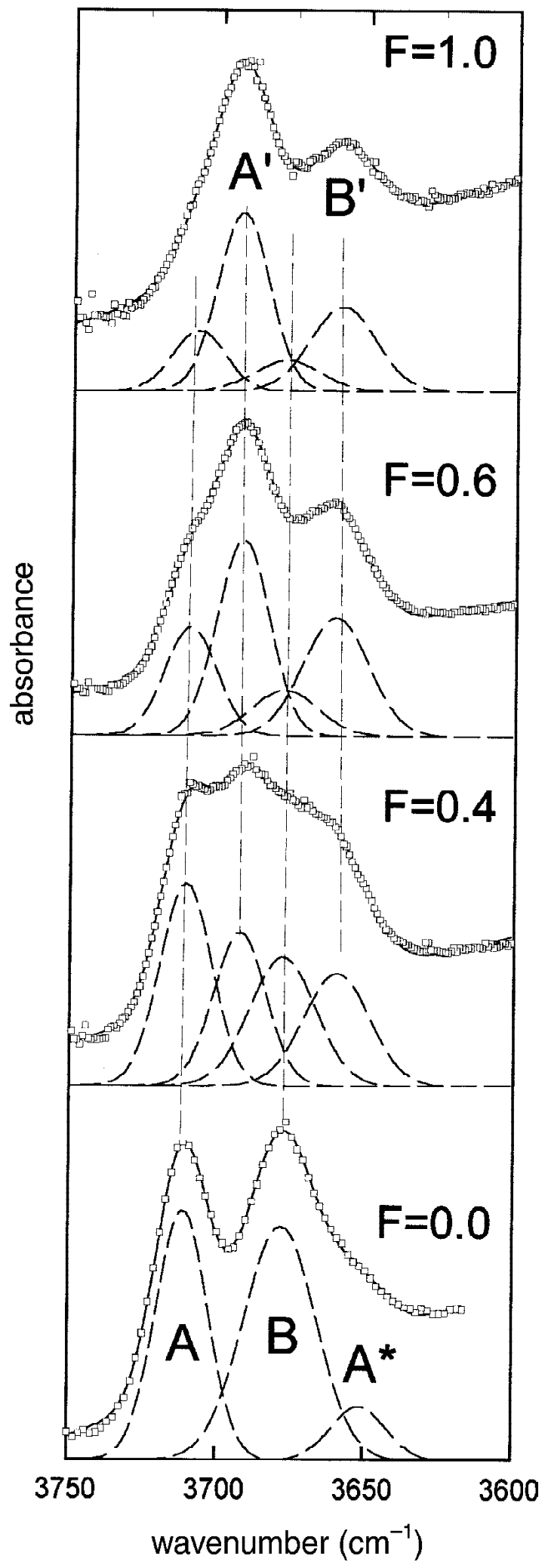

FigURE 5. Infrared spectra of Figure 4 resolved into symmetric Gaussian bands; for band nomenclature, see text. 
ering all possible local cation arrangements around the $\mathrm{O} 3$ sites. Synthetic end-member pargasite has the following octahedral composition: (Welch and Knight 1999): $\mathrm{M} 1=2.0 \mathrm{Mg}$; M2 = $1.50 \mathrm{Mg}+0.50 \mathrm{Al}$ and $\mathrm{M} 3=0.5 \mathrm{Mg}+0.5 \mathrm{Al}$. Hence, there are only two possible arrangements around each $\mathrm{OH}$ group: ${ }^{\mathrm{M} 1} \mathrm{Mg}^{\mathrm{Ml}} \mathrm{Mg}^{\mathrm{M} 3} \mathrm{Mg}$ and ${ }^{\mathrm{Ml}} \mathrm{Mg}^{\mathrm{Ml}} \mathrm{Mg}^{\mathrm{M} 3} \mathrm{Al}$. These must occur in equal amounts, in accord with the equal intensities of the two bands in the infrared spectrum of pargasite (Fig. 4). Each of these two configurations can be associated with three anion arrangements: $\mathrm{OH}-\mathrm{OH}, \mathrm{OH}-\mathrm{F}$, and F-F that couple through the A-site (Robert et al. 1999), giving a total of 13 possibilities (Table 4). Configurations 3, 6, 10, and 13 are invisible to infrared in the $\mathrm{OH}$-stretching region, 11 and 12 are degenerate, and configurations 5,8 , and 12 have very low probability of occurrence (Robert et al. 1993, 1997; Papin et al. 1997).

As shown by Robert et al. (1999), local OH-F short-rangeorder (SRO) can be tested from the relative intensities of the A-A' and B-B' doublets. Figure 6 shows the relation between the intensity of the F-related $\left(\mathrm{A}^{\prime}+\mathrm{B}^{\prime}\right)$ bands and the nominal $\mathrm{F}$ content in the system. In the range $0<X_{\mathrm{F}}<0.5-0.6$, the data lie along the 1:1 line. There are two plausible reasons for deviations of the data points in Figure 6 from the 1:1 line: (1) the actual amount of $F$ present in the sample is different from the nominal amount; (2) there is SRO of OH-F. Both the EDS data and the unit-cell parameters show that, over the range $0<X_{\mathrm{F}}<$ 0.6 , the samples contain the nominal amount of F; therefore, these samples must show SR disorder of OH-F. In the range $0.6<X_{\mathrm{F}}<1.0$, the actual $\mathrm{F}$ content of the crystals is significantly less than the nominal amount (Table 1). This accounts quantitatively for the deviation from linearity in Figure 6, suggesting SR disordered of OH-F over this range as well.

The greater decrease in intensity of the B-band (MgMgAl$\mathrm{OH})$ relative to the A-band $(\mathrm{MgMgMg}-\mathrm{OH})$ as a function of $\mathrm{F}$ (Fig. 4) indicates a decrease in the relative number of $\mathrm{MgMgAl}$ environments with increasing $\mathrm{F}$. Two possible mechanisms could lead to such a change. The first is progressive ordering of $\mathrm{Al}$ at the $\mathrm{M} 2$ site, induced by the replacement of $\mathrm{OH}$ by $\mathrm{F}$ at the $\mathrm{O} 3$ site. This process is probably operative in this system,

TABLE 4. Local configurations around the A site in synthetic amphiboles along the join pargasite-fluoropargasite

\begin{tabular}{|c|c|c|c|c|c|c|}
\hline & \multicolumn{4}{|c|}{ Configuration } & \multicolumn{2}{|c|}{ Band } \\
\hline & $\mathrm{M} 1 \mathrm{M} 1 \mathrm{M} 3$ & O3 & A & $\mathrm{O} 3$ & M1M1M3 & $A$ \\
\hline 1 & $\mathrm{MgMgMg}$ & $\mathrm{OH}$ & $\mathrm{Na}$ & $\mathrm{OH}$ & MgMgMg & $A^{\prime}$ \\
\hline 2 & MgMgMg & $\mathrm{OH}$ & $\mathrm{Na}$ & $\mathrm{F}$ & MgMgMg & - \\
\hline 3 & MgMgMg & $\mathrm{F}$ & $\mathrm{Na}$ & $\mathrm{F}$ & MgMgMg & \\
\hline 4 & $\mathrm{MgMgAl}$ & $\mathrm{OH}$ & $\mathrm{Na}$ & $\mathrm{OH}$ & $\mathrm{MgMgAl}$ & B \\
\hline 5 & MgMgAl & $\mathrm{OH}$ & $\mathrm{Na}$ & $\mathrm{F}$ & MgMgAl & $\mathrm{B}^{\prime}$ \\
\hline 6 & MgMgAl & $\mathrm{F}$ & $\mathrm{Na}$ & $F$ & MgMgAl & - \\
\hline 7 & MgMgMg & $\mathrm{OH}$ & $\mathrm{Na}$ & $\mathrm{OH}$ & $\mathrm{MgMgAl}$ & $A+B$ \\
\hline 8 & MgMgMg & $\mathrm{OH}$ & $\mathrm{Na}$ & $\mathrm{F}$ & MgMgAl & $A^{\prime}$ \\
\hline 9 & MgMgMg & $\mathrm{F}$ & $\mathrm{Na}$ & $\mathrm{OH}$ & MgMgAl & $\mathrm{B}^{\prime}$ \\
\hline 10 & MgMgMg & $\mathrm{F}$ & $\mathrm{Na}$ & $\mathrm{F}$ & MgMgAl & - \\
\hline 11 & MgMgMg & $\mathrm{OH}$ & $\square$ & $\mathrm{OH}$ & MgMgAl & $A^{*}$ \\
\hline 12 & MgMgMg & $\mathrm{OH}$ & & $\mathrm{F}$ & MgMgAl & $A^{*}$ \\
\hline 13 & MgMgMg & $\mathrm{F}$ & & $\mathrm{F}$ & MgMgAl & - \\
\hline
\end{tabular}

Notes: Local configurations 3, 6, 10, and 13 do not involve $\mathrm{OH}$ and hence produce no signature in this region of the infrared; bands 11 and 12 are degenerate. as single-crystal structure refinement shows complete ordering of Al at M2 in fluoropargasite (Oberti et al. 1995b). The second is progressive departure of the amphibole composition toward edenite. Both the cell dimensions and compositional data indicate that for $X_{\mathrm{F}}>0.5$, this second mechanism is also operative.

\section{The $\mathrm{OH} \leftrightarrow \mathrm{F}$ substitution in pargasite}

Complete OH-F solid solutions in amphiboles have been synthesized only for tremolite, richterite, and potassicrichterite compositions (Robert et al. 1989, 1999). In micas, the octahedral configuration around the anion site strongly controls the incorporation of F. In water-free conditions, stoichiometric F trioctahedral (phlogopite) and dioctahedral (muscovite) micas can be synthesized (Shell and Ivey 1969). However, under hydrothermal conditions, the $\mathrm{F}$ content is several times higher in phlogopite than in muscovite at constant $\mathrm{F}$ activity in the fluid phase. In tetrasilicic magnesium mica with mixed trioctahedraldioctahedral character, the partition coefficient of $\mathrm{F}$ between trioctahedral and dioctahedral arrangements $\left[D_{\mathrm{F}}=(\mathrm{F} / \mathrm{OH})_{\mathrm{Tr}} l\right.$ $\left.(\mathrm{F} / \mathrm{OH})_{\mathrm{Di}}\right]$ is $\approx 22$ (Robert et al. 1993). This fact is interpreted in terms of local bond-valence requirements around the $\mathrm{OH}$ group in the different environments. The data presented here suggest a similar control from the local octahedral configuration over $\mathrm{OH}-\mathrm{F}$ exchange in the amphibole structure. In Alfree amphiboles such as tremolite or richterite, the $\mathrm{OH}$ groups have no (or negligible) interaction with the NNN O atoms, and can be exchanged by $\mathrm{F}$ in all proportions with a short-range disordered OH-F distribution as shown by infrared data (Robert et al. 1989, 1999). In pargasite, the $\mathrm{OH}$ groups are bonded to two different types of $\mathrm{NN}$ configurations, $\mathrm{MgMgMg}$ trimers and $\mathrm{MgMgAl}$ trimers occurring in the ratio 1:1. The former is locally in the same arrangement as in richterite, and OH-F

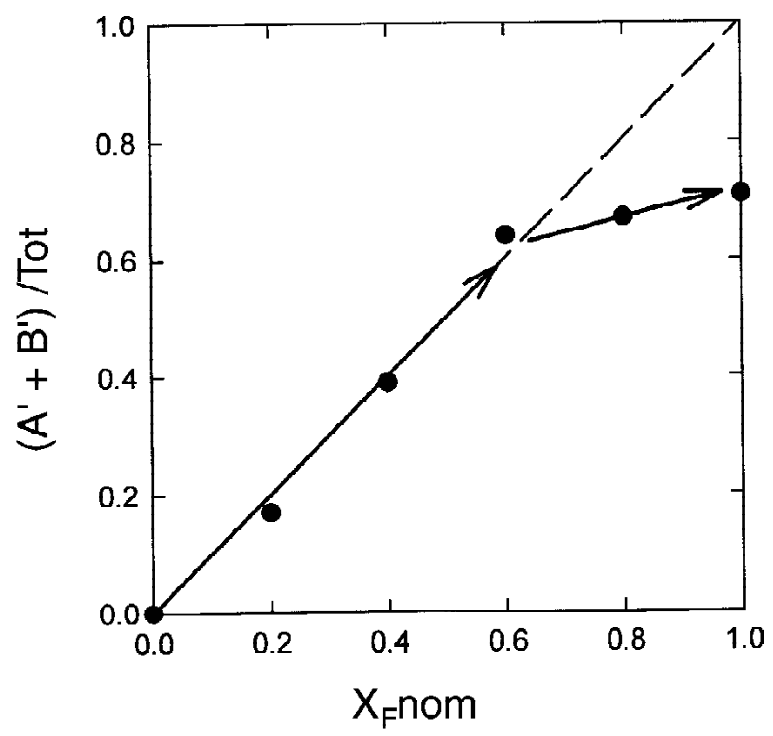

FIGURE 6. Comparison between nominal and IR-derived F content in synthetic amphiboles along the join pargasite-fluoropargasite. 
exchange is easy. Due to local bond-valence requirements, the $\mathrm{OH}$ groups involved in the $\mathrm{MgMgAl}$ trimers have significant interaction with the NNN O atoms and are less favorable for F$\mathrm{OH}$ exchange. This explains why the solubility limit is restricted at 1 apfu in pargasite and suggests that the ${ }^{[6]} \mathrm{Mg} /{ }^{[6]} \mathrm{Al}$ distribution in amphiboles has a key crystal-chemical influence on $\mathrm{OH}-$ $\mathrm{F}$ exchange in the structure.

The success of synthesis of fluoropargasite at high temperature $\left(1200{ }^{\circ} \mathrm{C}\right)$ in $\mathrm{OH}$-free systems may be explained by the complete ordering of ${ }^{[6]} \mathrm{Al}$ at M2 (Oberti et al. 1995b). This implies that fluoropargasite has only $\mathrm{Mg}$ in the $\mathrm{NN}$ environment around the anion site which can thus be filled by $\mathrm{F}$, like in Al-free amphiboles.

\section{ACKNOWLEDGMENTS}

G.D.V. was supported by "Cofinanziamento MURST 1997-Relazioni tra struttura e proprietà dei minerali: analisi ed applicazioni." F.C.H. was supported by Operating and Equipment Grants from the Natural Sciences and Engineering Research Council of Canada. The positive criticism of A. Beran, M. KochMüller, and R. Oberti helped in improving the clarity of the manuscript.

\section{REFERENCES CITED}

Boshmann, K.F., Burns, P.C., Hawthorne, F.C., Raudsepp, M., and Turnock, A.C (1994) A-site disorder in synthetic fluor-edenite, a crystal structure study. Canadian Mineralogist, 32, 21-30.

Boyd, F.R. (1959) Hydrothermal investigations of amphiboles. In P.H. Abelson, Ed., Researches in Geochemistry, p. 377-396. Wiley, New York.

Braue, W. and Seck, H.A. (1977) Stability of pargasite-richterite solid-solutions at 1 $\mathrm{kb}$ water vapour pressure. Neues Jahrbuch für Mineralogie Abhandlungen, 130, 19-32.

Cameron, M. and Gibbs, G.V. (1973) The crystal satructure and bonding of fluortremolite: a comparison with hydroxyl tremolite. American Mineralogist, 58, $879-888$.

Carman, J.H. (1974) Synthetic sodium phlogopite and its two hydrates: stabilities, properties and mineralogical implications. American Mineralogist, 59, 261273.

Della Ventura, G., Robert, J.-L., Beny, J.-M., Raudsepp, M., and Hawthorne, F.C. (1993) The OH-F substitution in Ti-rich potassium-richterites: Rietveld structure refinement and FTIR and microRaman spectroscopic studies of synthetic amphiboles in the system $\mathrm{K}_{2} \mathrm{O}-\mathrm{Na}_{2} \mathrm{O}-\mathrm{CaO}-\mathrm{MgO}-\mathrm{SiO}_{2}-\mathrm{TiO}_{2}-\mathrm{H}_{2} \mathrm{O}-\mathrm{HF}$. American Mineralogist, 78, 978-985.

Della Ventura, G., Robert, J.-L., Hawthorne, F.C., and Prost, R. (1996) Short-range disorder of $\mathrm{Si}$ and $\mathrm{Ti}$ in the tetrahedral double-chain unit of synthetic Ti-bearing potassium-richterite. American Mineralogist, 81, 56-60.

Della Ventura, G., Robert, J.-L., Raudsepp, M., Hawthorne, F.C., and Welch, M.D. (1997) Site occupancies in synthetic monoclinic amphiboles: Rietveld structure refinement and infrared spectroscopy of (nikel, magnesium, cobalt) richterite. American Mineralogist, 82, 291-301.

Della Ventura, G., Robert, J.-L., Hawthorne, F.C., Welch, M.D., and Raudsepp, M. (1999a) Short-range order of cations in synthetic amphiboles along the richteritepargasite join. European Journal of Mineralogy, 11, 79-94

Della Ventura, G., Robert, J.-L., Hawthorne, F.C., Raudsepp, M., and Welch, M.D (1999b) Contrasting ${ }^{\left[{ }^{6]}\right.} \mathrm{Al}$ ordering in synthetic Mg-and Co-pargasite. Canadian Mineralogist, 36, 1237-1244.

Foley, S. (1991) High-pressure stability of the fluor- and hydroxy-endmembers of pargasite and K-richterite. Geochimica Cosmochimica Acta, 55, 2689-2694.

Gilbert, M.C. (1969) Reconnaissance study of the stability of amphiboles at high pressure. Carnegie Institution of Washington Year Book, 67, 167-170.

Graham, C.M. and Navrotsky, A. (1986) Thermochemistry of the tremolite-edenite amphiboles using fluorine analogues, and applications to amphibole-plagioclase-quartz equilibria. Contributions to Mineralogy and Petrology, 93, 18-32.

Hamilton, D.L. and Henderson, C.M.B. (1968) The preparation of silicate compositions by a gelling method. Mineralogical Magazine, 36, 832-838.

Hinrichsen, T. and Schürmann, K. (1977) Experimental investigations on the $\mathrm{Na} / \mathrm{K}$ substitution in edenites and pargasites. Neues Jahrbuch für Mineralogie Abhandlungen, 130, 12-18.

Holloway, J.R. (1973) The system pargasite- $\mathrm{H}_{2} \mathrm{O}-\mathrm{CO}_{2}$ : a model for melting of a hydrous mineral with a mixed-volatile fluid-I. Experimental results to $8 \mathrm{kbar}$ Geochimica Cosmochimica Acta, 37, 12-18.
Holloway, J.R. and Ford, C.E. (1975) Fluid-absent melting of the fluoro-hydroxy amphibole pargasite. Earth and Planetary Science Letters, 25, 44-48.

Oba, T. (1980) Phase relations on the tremolite-pargasite join. Contributions to Mineralogy and Petrology, 71, 247-256.

Oberti, R., Hawthorne, F.C., Ungaretti L., and Cannillo, E. (1995a) ${ }^{\left[{ }^{[6}\right.} \mathrm{Al}$ disorder in amphiboles from mantle peridotites. Canadian Mineralogist, 33, 867-878.

Oberti, R., Sardone, N., Hawthorne, F.C., Raudsepp, M., and Turnock, A. (1995b) Synthesis and crystal-structure refinement of synthetic fluor-pargasite. Canadian Mineralogist, 33, 25-31.

Oberti, R., Hawthorne, F.C., and Camara, F. (1998) Synthetic fluoro-amphiboles: site preferences of $\mathrm{Al}, \mathrm{Ga}, \mathrm{Sc}$ and inductive effects on octahedral mean bondlengths. Canadian Mineralogist, 36, 1245-1252.

Papin, A., Sergent, J., and Robert, J.-L. (1997) Intersite OH-F distribution in an Alrich synthetic phlogopite. European Journal of Mineralogy, 9, 501-508.

Petersen, E.U., Essene, J., Peacor, D.R., and Valley, J.W. (1982) Fluorine end-member micas and amphiboles. American Mineralogist, 67, 538-544.

Raudsepp, M., Turnock, A.C., Hawthorne, F.C., Sheriff, B.L., and Hartman, J.S. (1987) Characterization of synthetic pargasitic amphiboles $\left(\mathrm{NaCa}_{2} \mathrm{Mg}_{4} \mathrm{M}^{3+} \mathrm{Si}_{6} \mathrm{Al}_{2} \mathrm{O}_{22}(\mathrm{OH}, \mathrm{F})_{2} ; \mathrm{M}^{3+}=\mathrm{Al}, \mathrm{Cr}^{3+}, \mathrm{Ga}, \mathrm{Fe}^{3+}, \mathrm{Sc}, \mathrm{In}\right)$ by infrared spectroscopy, Rietveld structure refinement and ${ }^{27} \mathrm{Al}$ and ${ }^{29} \mathrm{Si}$ MAS NMR spectroscopy. American Mineralogist, 72, 580-593.

Robert, J.-L., Della Ventura, G.C., and Thauvin J.-L. (1989) The infrared OH-stretching region of synthetic richterites in the system $\mathrm{Na}_{2} \mathrm{O}-\mathrm{K}_{2} \mathrm{O}-\mathrm{CaO}-\mathrm{MgO}-\mathrm{SiO}_{2}-\mathrm{H}_{2} \mathrm{O}-\mathrm{HF}$. European Journal of Mineralogy, 1, 203-211.

Robert, J.-L., Bény, J.-M., Della Ventura, G.C., and Hardy, M. (1993) Fluorine in micas: crystal-chemical control of the $\mathrm{OH}-\mathrm{F}$ distribution between dioctahedral and trioctahedral sites. European Journal of Mineralogy, 5, 7-18.

Robert, J.-L., Gourdant, J.-P., Linnen, R.L., Rouer, O., and Benoist, P. (1997) Crystal-chemical relationships between $\mathrm{OH}, \mathrm{F}$ and $\mathrm{Na}$ in tourmalines. In Tourmaline 1997 Symposium, Abs. Volume, Nové Mesto na Morave, Czech Republic, p. 84-85.

Robert, J.-L., Della Ventura, G.C., and Hawthorne, F.C. (1999) Short-range disorder of $\mathrm{OH}$ and $\mathrm{F}$ in monoclinic amphiboles: an infrared study. American Mineralogist, 84, 86-91.

Semet, M.P. (1973) A crystal-chemical study of synthetic magnesiohastingsite. American Mineralogist, 58, 480-494.

Shannon, R.D. (1976) Revised effective ionic radii and systematic studies of interatomic distances in halides and chalcogenides. Acta Crystallographica, A32, $751-767$.

Shell, H. R. and Ivey, K.H. (1969) Fluorine micas. U.S. Dept. of the Interior, Bureau of Mines, 647, $291 \mathrm{p}$.

Valley, J.W., Petersen, E.U., Essene, E.J., and Bowman, J.R. (1982) Fluorphlogopite and fluortremolite in Adirondack marbles and calculated C-O-H-F fluid compositions. American Mineralogist, 67, 545-557.

Welch, M.D. and Graham, C.M. (1992) An experimental study of the glaucophanic amphiboles in the system $\mathrm{Na}_{2} \mathrm{O}-\mathrm{MgO}-\mathrm{Al}_{2} \mathrm{O}_{3}-\mathrm{SiO}_{2}-\mathrm{SiF}_{4}$ (NMASF): some implications for glaucophane stability in natural systems at high temperatures and pressures. Contributions to Mineralogy and Petrology, 111, 248-259.

Welch, M.D. and Knight, K.S. (1999) A neutron powder diffraction study of cation ordering in high-temperature synthetic amphiboles. European Journal of Mineralogy, 11, 321-331.

Welch, M.D., Kolodziejski, W., and Klinowski, J. (1994) A multinuclear NMR study of synthetic pargasite. American Mineralogist, 79, 261-268.

Welch, M.D., Liu, S., and Klinowski, J. (1998) ${ }^{29}$ Si MAS NMR systematics of calcic and sodic-calcic amphiboles. American Mineralogist, 83, 85-96.

Westrich, H.R. (1981) F-OH exchange equilibria between mica-amphibole pairs. Contributions to Mineralogy and Petrology, 78, 318-323.

Westrich, H.R. and Holloway, J.R. (1981) Experimental dehydration of pargasite and calculation of its entropy and Gibbs energy. American Journal of Sciences, 281, 922-934.

Westrich, H.R. and Navrotsky, A. (1981) Some thermodynamic properties of fluorapatite, fluorpargasite, and fluorphlogopite. American Journal of Sciences, 281, 1091-1103.

Wiles, D.B. and Young, R.A. (1981) A new computer program for Rietveld analysis of X-ray powder diffraction patterns. Journal of Applied Crystallography, 14, 149-151.

MANUSCRIPT RECEIVED MAY 28, 1999

MANUSCRIPT ACCEPTED FEBRUARY 17, 2000

PAPER HANDLED BY ROBERTA OBERTI 